\title{
Timothy Mo’s Man Sundae, and other overseas workers
}

Everyone knows who Man Friday is. The Man Sundae of my title refers to the titular hero and narrator of Timothy Mo's most recent novel, Renegade or Halo² (1999). The book's first chapter is appropriately concerned with first the body and then the name of the hero, or rather his naming, for though he has been 'loftily christened Rey Archimedes Blondel Castro' (7), he will travel through his story under a series of nicknames, pet names and noms de guerre. This multiplicity of names reflects his protean and adaptive nature as well as the scandal of his provenance, which affronts most of the usual categories of identity. ${ }^{1}$ Rey, or Sugar Rey, is the son of a Filipina bar-girl from Mactan and an African American serviceman. Not surprisingly, his anomalous appearance prompts his earliest schoolmates to call him Frankenstein, but while the nickname serves as the ignition for a recurring theme, the novel's interest in forms of monstrosity, it doesn't quite catch on in the playground, because Rey is 'too bright and friendly' to be Frankenstein's monster. In an early instance of complicity, he obligingly supplies a nickname for himself, when the other urchins are debating what he should be called.

'Halo-Halo', I replied. Well, this was an inspired witticism at my years but not totally original. However, it was enough to crease my contemporaries, Halo-Halo, or $\mathrm{Halo}^{2}$ in its shorthand form, being the many-hued and multi-textured confection of ice-cream, cereals, neon syrups, crystallised fruits, frosty shavings, leguminous preserves and bloated pulses that you can find under different names all over South Asia. Just one of the region's surprising constants, but at this time I alluded to variety, to delicious hotch-potch and inspired mixing, me as Man Sundae. (6-7)

For the rest of this essay I propose to exercise the critic's privilege of ruining a good joke, and to take seriously the invitation encoded in the wordplay to compare

\footnotetext{
${ }^{1}$ The hero's name represents a small forest of allusive (and ironic) signposts, to directions which this essay will not be able to follow in detail: these include Rey the sunshine optimist, inventive Archimedes, Blondel the loyal and romantic vagabond, Castro the revolutionary. His several nicknames compound this nominal overdetermination. Rey is rich in names if in nothing else.
} 
Timothy Mo’s Man Sundae with Daniel Defoe’s Man Friday, and to follow up some of the implications of this conjunction. I am interested in Friday as a figure of foreign labour, or someone who labours for a foreigner. Though the individual parallel with Defoe's novel is neither sustained nor structural, the felicitous pun strikes what I will argue is a keynote to Renegade, the theme of the foreign worker. Here Renegade, and Rey Castro, for all the hybridities of the novel and its hero, raise a thoroughly Filipino subject, but one which is also a topic in the literature of colonialism, very broadly conceived. The 'guest worker' may be seen as doubly alienated, displaced and dispossessed, as an alien in somebody else's place and culture, and in expending labour in the interest of another, often on highly disadvantageous terms. Without suggesting direct influence or speculating on authorial intention, this essay will sketch a tradition for this theme, filling out the Man Friday hint with an earlier and a later example, from Shakespeare and Conrad, of the figure of the foreign worker. An approach to Timothy Mo’s protagonist framed by these earlier instances is proposed as a way of bringing into relief some of the issues - of alienation, agency, and complicity - that Renegade raises in lively and troubling ways.

Mo’s Rey Castro has many names and nicknames. Defoe’s Friday has only one. But naming is also an issue in Robinson Crusoe, and Friday is, needless to say, not Friday’s name, which we never discover, and which it seems Crusoe never thinks to ask. Though much later the silence of Friday was to serve as the central theme of J. M. Coetzee's Foe, in Robinson Crusoe Friday does have a voice, and a personality and intelligence that sometimes give Crusoe more dialogue than he bargains for. Crusoe feels it is his duty to lecture Friday in Christian theology, the omnipotence of God and the wickedness of the Devil. "“But”, says [Friday] again, "if God much strong, much might as the devil, why God no kill the devil, so make him no more do wicked?”' (220). Crusoe is stumped by this, and has to pretend not have heard the question. Friday obligingly does convert to Christianity, however, which leads to another moment of linguistic contrast with what might be called the master discourse, when Friday declares he would like to go back to his own country and convert his countrymen to Christianity and postcannibalism. Crusoe says teasingly that they will kill him. 'He looked grave at that, and 
then said, “No, they no kill me, they willing love learn.” He meant by this, they would be willing to learn’ (226). Crusoe’s ponderous and redundant gloss on Friday’s excellent English - 'they willing love learn' - is a small instance of the large sense in which Friday's wit and inventiveness is enclosed in the service of Crusoe's interest, just as Friday’s speech is inscribed and contained (in both senses) in Crusoe’s language. ${ }^{2}$

Crusoe describes the three years he lived on the island with Friday as 'perfectly and completely happy’ (222), and indeed Friday is clearly a delightful companion, as well as just the person you would want to have along on a desert island - goodhumoured, hard-working, optimistic and versatile: not unlike Rey Castro in Renegade. But although Crusoe is undoubtedly fond of Friday, Friday is always primarily valued because he is profitable. Crusoe's unconscious has made this point to him even before he rescues Friday, an action prompted by a dream in which he sees a savage escape from his cannibal captors and come to Crusoe's fort. In the dream, Crusoe shows himself to the savage, who kneels down before him; whereupon, Crusoe says, 'I carried him into my cave, and he became my servant' (202). In the dream, Friday arrives in Crusoe's territory as a refugee, and stays as a guest worker. The dream, clearly enacting Crusoe's wish, soon becomes actuality. Not long after rescuing him, Crusoe puts Friday to work and to school. The secular aim of Crusoe's educational programme is 'to teach him every thing that was proper to make him useful, handy, and helpful’ (213). The first lesson, as everyone remembers, is a naming, in which 'I made him know his name should be Friday, which was the day I saved his life; I called him so for the memory of the time; I likewise taught him to say Master, and then let him know, that was to be my name...' (209). Friday's name, then, has two meanings, as the invocation or invoice of an unpayable debt, and as the antonym or opposite of Master.

Suspicious by nature to the point of paranoia, Crusoe cannot bring himself to trust Friday at first. He is afraid that if Friday is able to return to his own people, he will forget his new religion, and his obligation to the man who has saved his life, and will come back

\footnotetext{
${ }^{2}$ I am indebted to the discussion of master-servant dialogue, in Robinson Crusoe and other novels, in Robbins, 53-90.
} 
to the island with 'a hundred or two' (225) of his countrymen, to eat his former master. This anxiety about the convert's reversion is a familiar theme of the colonial imagination. This leads to the strange situation in which one of the only two inhabitants of the island has the other under surveillance secretly, 'every day pumping him to see if he would discover any of the new thoughts, which I suspected were in him’ (225). But he has nothing to worry about. Bound to Crusoe by a compelling bond of gratitude, Friday is in effect detribalised, his entire loyalty now invested in his master, whom he serves unswervingly for the rest of his life. On the island Friday, kitted out in a suit of clothes that mimics Crusoe's own, is soon established as the indispensable servant, and he puts at his master's disposal many skills that Crusoe himself lacks. This is the team that enables Crusoe to consolidate his mastery over the physical space of the island, and over all the interlopers who land there. Friday is without self-interest. He fights Crusoe’s battles. He is jocularly described as lieutenant-general to Crusoe's generalissimo in the fight with the mutineers (264), and when Crusoe can finally leave the island and return to Europe there is no question of Friday going anywhere but with his master. In Europe Crusoe can engage other servants. Friday is no longer indispensable as he was on the island. But he finds a new role for himself as entertainer, providing amusement for Crusoe and his party by tormenting and humiliating a bear they encounter in the Pyrenees, before shooting it dead. Bear or mutineers or savages, Crusoe’s enemies are Friday’s enemies, and Friday is entirely instrumental to Crusoe’s projects and purposes, which he serves without question. In the narrative he is consistently referred to as 'my man Friday', a title which he has carried beyond Defoe’s book into popular usage as Man Friday. This leads us back, finally, to Rey Castro’s joke about how the 'delicious hotch-potch' of his own exotic ethnic confection makes him a kind of Man Sundae. But 'Man', in 'Man Friday', means servant. Man Friday is not his own man. And nor, as we shall see, is Man Sundae.

Renegade is a novel very interested in the question of what it means to be a man. It starts with a sort of parody of the traditional opening of heroic or hagiographic narratives, evidence of early miracles that signal the egregious nature of the subject. In Rey Castro's case this is literal evidence of his exceptional manhood, manifested for all to see as the child washes at the muddy standpipe near his home in the barrio, causing 
passing strangers to stop and stare in admiration. Even as a small boy, Rey is already quite a man, and when he grows up he will become a basketball hero, with a formidable capacity for physical labour and, when there is no alternative, for fighting. But this Man Sundae is also destined to be a man in the Man Friday sense, a generally uncomplaining instrument of other people’s interests, an engine of alienated labour. Sugar Rey’s masculinity makes him a man, but his class and provenance and luck will ensure a career as somebody else's man, and therefore less than a man or less than what a man ought to be, a 'man' as half of a relationship requiring completion by another who is 'master', as was made clear to Friday in his first lesson at the hands of Robinson Crusoe. Rey's complex identity and multi-faceted characterization are in a sense contradicted or ironized by the brute fact of his serial subordination to others, just as his powerful physique is contradicted by his career as a docile body, a gentle giant doing other people’s bidding.

'A Halo ${ }^{2}$ is a whole bunch of ingredients that shouldn't belong together but work when you combine them' (231-2), Rey explains to one of these masters, the English dentist Commander Smith. Indeed Rey is overdetermined in his hybridity. ${ }^{3}$ As an African American Asian, he has parents whose own identity is already rich in complexity. His Filipina mother is described as 'a mountain-girl from Mindanao: half-lowland Malay, half-highland aboriginal, with a trace of philandering Chinese trader somewhere in the family tree' (7), and his father, whom he never knew, contributes a genetic inheritance at least as laden with problematic history. Once he has been given a religious and classical education by American and English Jesuits, and acquired some training as a lawyer, Rey by the time he sets out on his travels is already a strange confection, a throwing-together of natural and cultural ingredients, and in one sense a man of the world. This hybridity has plenty of implications. Hybridity is sometimes seen in postcolonial writing as an opportunity to confuse and give the slip to discourses of oppression. It does not work like this for Rey Castro. The confection of his provenance ensures that he is a person who is going to be an anomaly everywhere, even in the barrio where he grows up, where his outlandish appearance presented his schoolmates, as we have seen, with a sort of crisis of

\footnotetext{
${ }^{3}$ For a review of the treatment of the theme of race and ethnicity in Mo’s earlier fiction, see Lim.
} 
nomenclature. He is a mixture of a large number of ingredients, and an example of none. Occupying a category practically sui generis, he inherits no patrimony of loyalty, and he is bound to be a foreigner to everyone, including to everyone he works for. This is a particularly important point in view of the fact that the world he moves through is to an extraordinary extent presented as a series of tribal territories. In a novel which is obsessed with the idea of context, which will send its picaresque hero on a journey across the region (Philippines, Hong Kong, Malaysia) and later to the Middle East, Europe and the Caribbean, Rey Castro seems to be a person whose proper context is nowhere. ${ }^{4}$ From time to time he likens his career to a game of snakes and ladders, where a throw of the dice may send him zooming up a ladder of opportunity or slithering down a snake of disaster, and this is peculiarly appropriate to the way the novel is mapped, both geographically and in its spatial form, as a series of spaces of experience, each with its own tribe and customs, not unlike the chessboard Alice moves across in Through the Looking Glass.

Castro then is the only non-tribal in a tribal world. Not only is he a scandal to tribalism in his complex hybridity, which does indeed make him neither one thing nor another, like the creature in Frankenstein which his schoolmates think he resembles. His education at the hands of the Jesuits also gives him, or so he believes, a disposition to aloofness, the stance of a critical outsider. 'Father Paul's great gift to me was the ability to be dispassionate about myself, to see things cold-eyed from the outside.... What he gave me, Castro the sneak, the wind-up dinosaur, was a cool heart and a permanent emancipation from tribalism' (32-3). Although he is entirely affable and sociable, and makes friends wherever he goes, Castro is marked as an outsider, a man with no place but many names. His work then is doubly alienated: he works for a master or a set of masters who are also alien to himself. On the strength of this complicity - one meaning of which is doing other people’s dirty work for them - I wish to view Rey Castro in a tradition of literary representations of alien labour which includes Othello, the black guest worker

\footnotetext{
4 'Context' is Rey's watchword, his principal tool for understanding people in the world. He claims to have acquired his sensitivity to 'context' from his Jesuit education. Typically, however, he believes he can see himself differently: 'I prided myself on the ability to rise above a context, viewing myself dispassionately
} 
who has done the state some service and thinks that they know it, Crusoe's Friday, that 'most dextrous fellow' (226), and Conrad's Nostromo, the Italian cargador who saves Sulaco, and whose name means ‘our man'.

After his schooling at the hands of the Jesuits, Castro is sent to college as a scholarship boy to study the law, and soon finds himself working for Atty Caladong, a Filipino lawyer enriching himself by offering non-existent help to Vietnamese boat people who are desperate to emigrate to America. Castro the permanent outsider feels sympathy with the refugees - one of whom happens to be an Afro-Asian like himself and is entirely aware of what Atty Caladong is up to. His complaisance in this and still more dubious enterprises has led Elaine Yee Lin Ho, in her book on Mo’s novels, to speak not of Castro's 'cool heart' but of his 'emotional dereliction' and 'lack of affect'. When he himself becomes a fugitive, Castro will fetch up in Hong Kong where he devotes his services to the English Commander Smith and his family, who find him indispensable but still leave him behind when they have to return to England, and who will not be able to make the effort to meet him again when he comes to London in a later chapter. As an illegal worker in the Middle East, he labours uncomplainingly for the spectacularly corrupt Faud, and carries the bag on a smuggling expedition. Still illegal in London, he takes to the sea and serves in a series of vessels until he is wounded in a fight and forced to jump ship in Cuba. Finally he comes home to the Philippines. It is a colourful curriculum vitae, and one can imagine that his letters of reference would be impressive too; all his employers find Rey willing, hard-working, uncomplaining, indispensable.

Mo’s Rey Castro takes his place in the long line of the fictional representation of servants, explored in Bruce Robbins' excellent study The Servant's Hand. Most adult human beings work for somebody else. In placing Castro in a series of obliging foreigners in fiction which includes Othello, Friday and Nostromo, I want to draw attention to a tradition of partially self-defeating complicity. What these four have in

and neutrally at all times'. (394). For 'context', see 24, 45, 81, 141, 213, 230, 245, 320-1, 363, 367, 380, 394, 439. 
common is their devotion for good or ill to the designs and purposes of others' interests in some obvious ways incompatible with their own.

Othello is a great soldier. But everything we know of his provenance and priorities makes him extraordinarily anomalous in Venice, an African aristocrat and adventurer, with a hopelessly anachronistic sense of chivalry, employed by a Christian, commercial, intrigue-filled and racist city-state, bent on regional hegemony. When Othello wins the love of Desdemona, Brabantio her father attacks him in alienating and dehumanizing terms: he is an animal, a thing, or a devil. Othello is confident he can survive this attack - 'My services, which I have done the signiory, / Shall out-tongue his complaints' (I.ii 18-19) - but his confidence rests entirely on his usefulness, his service to the state, an appraisal not of what he is, but of what he can do. Anyone can see that Iago is able to destroy Othello so fast because Othello never really believed in himself as an authentic Venetian and worthy husband for Desdemona. As his crisis deepens he keeps clutching at his identity as a soldier, but Othello's sword is at the service of people who are in many ways as opposite to himself as black to white. The dreadful confusions of this situation culminate in the last moments of Othello's life, after he has murdered Desdemona, when he likens himself to ‘the base Indian' (V.ii 348) who threw away a priceless pearl in ignorance, presumably, of its exchange value in markets outside his own simple community. This strange and estranging ethnic and cultural affiliation - for what could place him further from the Venetian grandees who are his audience, to whose kinship he has aspired? - is followed by a simile comparing his remorseful tears to the gum dropped by Arabian trees, another orientalizing figure that removes him further from the world of Venetian civilization. Then this:

[S]et you down this, And say besides, that in Aleppo once, Where a malignant and a turban'd Turk Beat a Venetian, and traduc'd the state, I took by the throat the circumcised dog, And smote him thus. [Stabs himself.] (V.ii 352-7) 
In the reflexivity of his suicide, Othello as agent is mobilized to immobilize himself as foreigner and victim, just the kind of 'extravagant and wheeling stranger' (I.i 136) Brabantio was warned against. In his last moments Othello identifies himself simultaneously as the state's champion and as a pagan alien and enemy of the state - the 'turban'd Turk' - who has harmed a Venetian subject, and his last act of loyalty to Venice is to execute himself for insulting Venice. (The crazy identity politics of Othello's last speech ironically suggest that he has indeed finally qualified to belong to Venice. Who but a Venetian would confuse a Moor with a 'base Indian' and a 'turban'd Turk', and then stab him to death?)

Venice relied on Othello to secure regional domination and defeat its enemies. Likewise, Crusoe's success in subduing his island, and turning it into a profitable colony, depends on Friday's labour and his military skills, without in obvious ways working to Friday’s own interest (he will never be able to return to his own country, for example, and there is no evidence that he ever gets paid). Friday remains, however, an uncomplaining subaltern, Crusoe's junior officer, throughout. Conrad’s Nostromo offers another example. Exploited and patronised by almost all the major players in the political drama of Costaguana, the Capitaz de Cargadores is a sedulous puppet. Holroyd, the distant American financier and one of the earliest characterizations of global capital in fiction, purchases Charles Gould as his 'man' in Costaguana entrusted with fulfilling the manifest destiny of profit, and Nostromo is 'our man' in the service of the Gould concession and its allies. Nostromo is thus doubly the instrument of 'material interests' which benefit him very little, and yet are entirely dependent on his services.

In this novel which concerns itself as much as Robinson Crusoe with questions of value, the 'extraordinary value’ of Nostromo’s services is emphasized from the start, and not only to his employer Captain Mitchell, who 'in the innocence of his pride was already developing that mania for "lending you my Capataz de Cargadores" which was to bring Nostromo into personal contact, sooner or later, with every European in Sulaco’ (48). He is an asset, indeed a treasure - a prodigy of strength, courage and leadership. Conrad seems to enjoy heaping praise on the indispensable Nostromo, while allowing that his 
work profits everyone but himself. His exploits are those of a storybook hero: he performs two signal acts of heroism which do secure the future of Sulaco, and enable the founding of the Occidental Republic and the continuing profitability of the material interests of Gould and Holroyd. It is after his return from risking his life to save the treasure of the San Tomé mine that Nostromo begins to feel the asymmetry of his relations with his employers, who seem to have neither reward nor gratitude to offer. He has kept a fabulous hoard of silver ingots from the hands of the enemy, yet he himself has returned with bare feet and head, with one shirt and a pair of cotton calzoneros for all worldly possessions.

The facts of his situation he could appreciate like a man with a distinct experience of the country. He saw them clearly. He was as if sobered after a long bout of intoxication. His fidelity had been taken advantage of.... He had been betrayed! With the boundless shadows of the sea behind him, out of his silence and immobility, facing the lofty shapes of the lower peaks crowded around the white, misty sheen of Higuerota, Nostromo laughed aloud again, sprang abruptly to his feet, and stood still. He must go. But where? (344-5)

Note how he springs into action, but is immediately paralyzed. Strength without agency is the characteristic of his predicament, for indeed there is nowhere for him to go, being what he is, the incomparable and loyal Nostromo. In fact his next journey will be another service performed to save the skins of the Blancos, his legendary ride across the mountains to bring the army of Barrios to Sulaco. Later, a prisoner of his reputation for selflessness and honour, he is preyed upon by the secret of the treasure which he is unable to possess for himself. In this exquisite powerlessness he continues, until by misadventure he is mortally wounded by (of all people) another hero of the people, the old Garibaldino Giorgio Viola. Nostromo even tries on his deathbed to pass on the secret of the silver to Emilia Gould, for she has always been good to the poor. But he has chosen to confide in the one person who believes the hoard is better lost for ever. ${ }^{5}$ And so he dies in 'miserable subjection’ (458), though his employer Captain Mitchell’s

\footnotetext{
${ }^{5}$ In a particularly sardonic irony, Nostromo offers her the secret because she has always seemed the only one of her class to care for the poor. She is by now disgusted with the 'material interests' that drive her husband and his allies, and she refuses the secret, declaring the lost silver to be 'nothing of importance', because she can afford to. See the discussion in Carpenter.
} 
description of him as 'a man worth his weight in gold' (434) had been in fact a grotesque understatement.

All these men - Othello, Friday, Nostromo - are agents, but without agency, providing an essential service complicit in the interests of more powerful groups, without being admitted to these groups, and often to the detriment of themselves and of other people with whom they seem to have more in common than they do with their masters. It is in this company that Mo’s Rey Castro can take his place.

Castro is not just a servant and labourer. Like all of Mo’s novels, Renegade is punctuated by moments of violence, and it is frequently in these crises of violence that Rey Castro’s complicity is dramatized most forcefully. At law school, where rich kids and scholarship boys mix, he is recruited for a fraternity gang fight which gets out of hand, leaving a boy dead. The next incident is more disturbing, when some of the fraternity get high and gang-rape a bar-girl, Haydee, and then murder her. Rey refuses to take part in the rape, but yields to peer pressure to share out responsibility for the crime, as each of the 'brothers' is lined up to stab the body of the already dead victim, in a shocking dramatization of complicity.

We could have been lining up to kiss the Pope's toe. Haydee, of course, didn’t even quiver as Skipper stuck the knife in her. Dant looked at me. I raised eyebrows, meaning, yes, do it.... I took the knife from Skip and did it. There was no more resistance or drama than there would have been stabbing a foam-cushion. (113)

The banal similitude about the foam cushion does nothing to make the moment less repulsive, serving if anything to emphasize the eerily non-committal tone of the account, which is especially distressing in that the victim, who was a friend of theirs, has reminded Rey and his friend Danton of their mothers, both of them bar-girls $(106,111)$. Castro aligns himself with the spoilt fraternity kids in a crime perpetrated on his own class, and makes it worse when he helps to dispose of the body, which they dump in waste ground, and later go back to bury. 'This was a cultural imperative, man: to keep my trap shut and my face blank' (114). Finally, the brothers set Castro up to take the blame for the murder. 
The worst outrages in the story are committed against Rey's friends and associates. There are four rapes or attempted rapes in the story. Rey will soon be forced to watch from his hiding-place while his friend Danton is raped and murdered by Ukrainian sailors. He is able to intervene and prevent the third and fourth attempted rapes, though it would be hard to argue that this indicates a radical change in his character or the raising of his political consciousness. Renegade is not a Bildungsroman if that term indicates some progressive moral education or character development. The hero is a product of his environment, what Rey likes to call 'context': the realities of the context do not change and the hero does not change either. There is no progress in Rey's narrative, just displacement, as incidents may echo but do not build on earlier incidents. One more example will suffice. When Rey is working as an illegal labourer in the Middle East, he is driven out into the desert with his work detail, all of them Filipinos, to some sinister and featureless place 'up the fundamental end of nowhere' (250), where they discover that their assignment is to unearth a mass grave and rebury the decomposing bodies. This gruesome work is attended with much hysterical joking, and especially when the head comes off one of the corpses - until, that is, Rey takes a close look and sees that the head has an undeniably Filipino face. Rey never discovers - or never reveals - how or why these Filipinos died or who ordered their reburial, and the incident is strangely without consequences. But it is interestingly reminiscent of the disposal of Haydee's corpse, with Rey once again cleaning up after a crime in which he has much more in common with the victim than with the perpetrators. On behalf of the work detail, he speaks a eulogy over the dead.

They travelled far, like ourselves, in search of a livelihood and to provide a better life for those they left at home. Let us honour their sacrifice but let us not shed too many tears for them, for they were poor men like ourselves, strangers in a strange land, and it is not graceful to pity yourself too much. (255)

Rey is easy-going and sociably disposed, his great strength gives him confidence, and inspires it in others. 'When they got to know me,' he says, 'folks felt so easy with Sugar, they made me an honorary them' (365). He is not a troublemaker, and he fits in 
easily. This is a great gift in a world which is represented as a checkerboard of tribal territories with interests to promote and defend. But Rey's typically optimistic observation is not really accurate. He is only granted honorary themhood by virtue of being useful, like Friday and the others. He is no more a member of the English Smith family than Othello is a Venetian. His ethnicity gives him membership of a statistically insignificant minority, what he calls 'the Lost Tribe of Amerasians' (215). ${ }^{6}$ All the other tribes in the story, including the Filipinos, look on him as an outsider, however obliging. He belongs only to the community of the powerless. They are his people, and whoever he is working for, they are the ones who are likely to suffer, other people's agents who have no agency of their own. That is the way the world works. When the weak work for the powerful, they join a conspiracy against themselves.

How long we stayed wasn’t a big source of concern to me. My time hadn't been my own since I scrambled fifty feet up the side of the freighter in Manila Bay. It was all the same to me. I'd climbed half a hundred feet but descended into another world, that of the international under-class who were the slaves of our century. (327)

As Phillip Darby has pointed out, postcolonial theory which works on an essentially discursive model can be inclined to construe the scope of agency too broadly. (Darby, 225) Agency in the sense of action to change one's environment and advance one's interest is hard to come by, and it is certainly not guaranteed by hybridity. Agency in the other sense, that of work as a representative or servant of somebody else's interest, is a condition that is materially and psychologically hard to escape. Not every Castro (or Danton) has his revolution.

But if Rey Castro spends virtually the whole story as somebody else's man (and boy), his function in the narration is another matter. Of the four intercontinental workers discussed here, only Friday is not granted eponymity. But only to Rey Castro is it given to tell his own story. ${ }^{7}$

\footnotetext{
${ }^{6}$ In the course of this novel with scores of characters, Rey meets only two other Amerasians, Michael the Vietnamese refugee, and DeLorna in Thailand.

${ }^{7}$ Othello, to be sure, has a tendency to autobiography, like all egotists. This is given rein in his so seductively recounting his adventures to Desdemona (he narrates his narrations in I.iii 128-68), and in his
} 
Powerless and placeless in the story, in the narrative he is monarch of all he surveys. He has the story to tell. In some sense narration is always an empowerment, though we need to be careful not to exaggerate sentimentally the consolations of narration; after all, the narrator of a victim story is still a victim. But any narrator has some control over the point of view from which the tale is offered to a reader, and the orientation from which its characters and issues are approached. While Rey Castro’s story has been for the most part that of a thoroughly reliable operative in the service of others, an awareness that his acceptance by others has been coterminous with his usefulness to them has sharpened the beady eye of reminiscence when the sometime agent turns into a narrator. The result is an extraordinarily unforgiving account of the world seen from underneath, with each of the tribes that have exploited, excluded, disappointed or betrayed Castro subject to his withering if genial generalizations. It is in this sense - in narration, rather than in action - that Rey qualifies for the title of Renegade, one who abandons an earlier loyalty to a cause or party.

As he travels the globe, viewing it from the underside, Rey is ever ready with hair-raising generalizations about the tribes he encounters - Chinese, Arabs, Singaporeans, English, Cubans, everyone else: ‘every moral judgement,' one reviewer complained, 'is expressed in racial terms.' (Korn) These are comprehensive satiric registrations largely without a positive term. Readers may be inclined to see them as evidence of a spectacular and unblushing racial prejudice (on the part of Castro), but arguably the motivation is as much a sort of anarchistic distaste of a singular man for the very idea of group identity and its tyrannical claims on the individual - the kind of claims that obliged Castro to knife the body of the dead bar-girl in the name of brotherhood. In this way the narrative might be seen as a sort of belated resistance to tribalism itself. Rey's complicity with the interests of the various tribes he encounters and serves (having no tribe of his own to speak of) is almost exactly matched with a dispassionate excoriation of different groups - classes, ethnicities, nationalities - as they cross the path 
of the narrative. The obliging servant becomes an unforgiving historian. 'I think of how much I hate and fear teams: the congregation and the gang, the crew and the tribe' (478). It is said that no man is a hero to his valet. The migrant worker may be forgiven for taking a similarly disenchanted view of the world which takes his or her labour, even when he or she is obliged to go on supplying it.

I have placed Rey Castro in a tradition of the representation of complicitous foreigners that belongs to the literary history of colonial discourse, broadly conceived. It could be argued, finally, that the autobiographer's generally hostile and possibly racist characterization of the story's tribes stands in for the postcolonial agency which is simply not available to him as a member of the global underclass. As he struggles across the tribal checkerboard uncomplainingly following his orders, it is as if Rey has been storing up the power to narrate and judge as freely, and ruthlessly, as his masters have used the power to command service. Sugar Rey Castro's narrative ends, however, when he returns from his world travels to the Philippines as a free agent for the first time in his life. Perhaps this ending might also be the moment for a different kind of story, and his career as a renegade, to begin.

\section{WORKS CITED}

Carpenter, Rebecca. 'From Naïveté to Knowledge: Emilia Gould and the "Kinder, Gentler” Imperialism.' Conradiana vol 29 no. 2, 1997. 83-100.

Coetzee, J. M. Foe. London: Penguin, 1987.

Conrad, Joseph. Nostromo: A Tale of the Seaboard. Harmondsworth: Penguin, 1972.

Darby, Phillip. The Fiction of Imperialism: Reading between International Relations and Postcolonialism. London and Washington: Cassell, 1998.

Defoe, Daniel. Robinson Crusoe. London: Penguin, 1985.

Ho, Elaine Yee Lin. Timothy Mo. Manchester: Manchester UP, 2000 (forthcoming).

Korn, Eric. Review of Timothy Mo, Renegade, or Halo ${ }^{2}$. TLS, 30 July 1999, 21.

Lim, Shirley Geok-lin. 'Race, National Identity, and the Subject in the Novels of Timothy Mo.' Fusion of Cultures? Ed. Peter O. Stummer and Christopher Balme.

Amsterdam and Atlanta, Ga.: Rodopi, 1996. 91-101.

Mo, Timothy. Renegade, or Halo² . London: Paddleless Press, 1999.

Robbins, Bruce. The Servant's Hand: English Fiction from Below. New York: Columbia UP, 1986.

Shakespeare, William. Othello. Arden edition, ed. M. R. Ridley. London: Methuen, 1977. 